\title{
ARBITRATION AND ADR, COMPONENTS OF THE NEW PARADIGM OF THE JUSTICE IN THE MODERNITY (*)
}

\author{
Silvia Barona Vilar \\ Prof. Dr. Dr. h.c. mult \\ Civil and Criminal Justice, MedArb ResearchGrup \\ Universitat València \\ Spain
}

\begin{abstract}
Arbitration is a piece of the new conception of Justice. The legislators have changed the rules of arbitration and there is a sort of uniform Act of global arbitration. CNUDMI Act is the protagonist of this metamorphosis. With some contractual and jurisdictional elements arbitration is arbitration and this is its real legal nature. Two fundamental elements constitute its essence. The freedom and autonomy of the parties, on the one side, and the exercise of the function of the arbitrators and its effects, on the other. There is not arbitration without them.
\end{abstract}

Keys: arbitration, new paradigm of Justice, ADR, CNUDMI

\section{Introduction. Justice' Perception in the $21^{\text {st }}$ Century}

All of the social transformations we have in the Modernity are representative of the new faces of Civil Justice in the 21 st Century. Our 21 st Century society is changing rapidly. It is very different to that of the $20^{\text {th }}$ century, and as a consequence of that also Justice has undergone enormous transformations affecting our idea of Justice and our Access to it. Some of these changes are already here. Some others will apparently come sooner or later.

The question is How do we perceive Justice in the 21st Century? It is indeed a simple question with a terribly difficult answer. To figure out how Justice is and will be in the $21^{\text {st }}$ Century we should perhaps place Justice on the sofa and following the theories of Sigmund Freud try to practice psychoanalysis with it. You already know how important it is to carry out a search, inside, in the conscious and in the unconscious, to find some ideas that allow us to know why and how to understand Justice.

$\left(^{*}\right)$ This research was made under projects DER 2016-74945-R (MINECO) (Psicoanálisis del Arbitraje: solución o problema en el actual paradigma de Justicia) and PROMETEO 2018/111 (“Claves de la Justicia civil y penal") 
In this task we should consider many ideas and facts. Let me stress now some of them:

1. First, we must be fully aware of the fact the human being is complicated.

2.- Secondly, complication generates conflicts. In fact, the more complex the society is, the higher level of complication we have, both in quantity and the difficulty of the disputes.

3.- This complexity and disputes arising out of it has recieved different attitudes and responses throughout History. Disputes were solved and peace was maintained in different ways depending on each historical moment.

Thus, in more primitive societies the solution to social conflicts was provided by the Tribal head. He had the power to expel from the tribe those who performed acts considered intolerable to society; Those thrown away were left unprotected, fully outside the community. Additionally in cases of a minor conflicts between the members of the tribe, the Chief of the tribe acted as a conciliator. Later on, in feudal societies the role of the lord was to "protect" his subjects, although this protective function was not exercised in a disinterested manner but usually in exchange for the payment of fees.

Gradually our society evolved and in the era of modernity became structured in States, with institutional power, as Machiavelli wrote in his work "The Prince". In this modern western society the shift of population from the countryside to the towns and cities took place. The period saw the consolidation of the nation-state as the main political entity. A public administrative structure was created. On the one hand, States offered security to their people, and on the other hand, the convergence of a strong state and the government of an astute prince were able to guarantee a social order. Not surprisingly these far-reaching developments led to increasing activity in political, moral and legal philosophy -the fields at whose intersection we find justice and the ways to solve conflictivity.

As Hobbes described in The Leviathan under the concepts of "Law and Order" this modern society saw the establishment of state-financed police services and of penal codes and systems of punishments. The State assumed the exercise of "ius puniendi". And regulated the model to solve the conflicts between the citizens: the process. 


\section{Process, as a conquest of civilization}

In this new model of structured societies linked to the idea of national States, the civil process was a conquest of civilization. It became the paradigm of Justice. A paradigm in which the State assumes the leading role. What are the characteristics of this process?

Firstly, it is a static model in which a procedure is regulated, with phases, characteristics, deadlines, subjects, etc. It provides security as regards actions to be undertaken and fostered predictability and certainty.

Secondly, this process is a model that stands on the idea of "heterocomposition". The judge supra partes- imposes the solution on them. The judge is the one in charge of solving the dispute "in" the course of the process.

Thirdly, it is a public model in which the State controls, directs and determines how the process and its guarantees are developed. It is practiced through state bodies, the Courts.

That public model was consolidated in modernity for both Civil and Criminal cases and it was only in the ninenteen Century that it splitted into two different processes depending on the interests involved: on the one hand, when the interests at stake are public and reprehensible conduct are crimes the State intervenes in the process. On the other hand, when the interests are personal, economic, labor, commercial, family, etc., is the people affected who decide to go to it.

But, the twentieth century was especially important because of the incorporation of an additional element into the model of public justice. Enormous expectations of guardianship were generated by the citizens, becoming aware that the State was the political entity that protected them, as citizens with rights. The State assumed the costs of Justice as a fundamental right and the political objective of improving it, favouring it, renewing it and guaranteeing it to everyone alike. So, the concept of Social Justice was developed, consistent with the welfare state and its social policies and the concept of Access to Justice acquires a social perspective, characteristic of the historical-political moment. In the $20^{\text {th }}$ Century the process becomes not only a constitutional right, but also the tool to maintain social peace and to solve conflicts.

The importance of knowledge and management of the process led to the consolidation of university education in the process, with the subject of Procedural Law and with a very important amount of scientific work that has allowed to maintain the study of the process, besides the jurisdiction and the action, in one of the core-subjects of legal studies. 
The 21 st century has dawned, however, with a very different reality. For many reasons, it is easy to observe how in the most prestigious foreign universities the subject of "Procedural Law" disappears from the curriculum of law, and the Chairs of "Procedural or Process Law" are replaced by "Justice", "Litigation" “ADR", "Evidence" or "Sentencing". Obviously, the process has not disappeared ${ }^{1}$. There it is, and it is subject to changes, successive modifications, constantly, some of them are contradictory, almost as if you wanted to find it in a "pill of happiness," as a method of transferring it to a third the competence to solve all evils. And, of course, we want a quick response, without excessive cost and favorable to anyone asks for it. The consequence of all this has led to the creation of a collapsed procedural model, without the adequate means to respond to this litigation explosion to which $\mathrm{OLSON}^{2}$ referred to at the end of the last century, generating a great dissatisfaction among citizens.

There are many coordinates that have influenced - and are currently influential- in that transformation of the process model. We are living as if we had a pathological obsession with legal reform by trying to adapt and convert a guarantor instrument into an instrument of effectiveness, which is an instrument for citizens accessing justice in a way to solve in real time the disputes of consumers, who have replaced citizens as subjects of protection.

The ideological parameters that inspire the society of the 21 st century have destroyed some of the old values of the twentieth century, especially those that erected Justice as one of the pillars of the social and democratic state. The Justice that interest us is one that works, certainly, but in terms of the analysis of what must be understood by the functioning of Justice have shed numerous components that, beyond the essential meaning of Justice as a guardianship of citizens, has been turned into mechanisms to alleviate the expansive litigiousness that society generates in some cases, and palliate it in the swiftest and least costly way possible, even at the expense of guarantees and rights.

In that context the sublime is the economy, and everything is measured under cost-benefit parameters; The process is not an instrument of justice, probably because justice is not more than one of the values of the legal order, the standard of modern society, and it is becoming a

\footnotetext{
${ }^{1}$ BARONA VILAR, S., "The Faces of Civil Justice in the Global Society of the 21st Century", ZZP Int. 21 (2016), pp. 74-75.

${ }^{2}$ OLSON, W.K., The litigation explosion: what happened when America unleashed the lawsuit, 1991.
} 
service for consumers and users, who look for a result, although it would not be the best result, but in any case $a$ result.

\section{Arbitration in this context. Arbitration is Arbitration}

Simultaniously with this model of public justice, arbitration has been a part of Civil Justice in the history. Arbitration has been and is an adjudicatory mechanism for the resolution of legal disputes which, despite its ancine origin, has been decisively promoted in the last years within the frame work of Alternative Dispute Resolution (ADR), and more and more On line Dispute Resolution.

One of the most debate about Arbitration has been what's Arbitration? Contract? Process? Function?

It is beyond doubt that the doctrinal wealth and variety arisen out of those scientific debates have been fruitful. The consolidation of the different components of arbitration is based upon them, and it is manifest that arbitration is formed of a series of plural legal relationships; some of them of obvious contractual nature; other of equally irrefutable public character.

It follows that the various elements that constitute arbitration appear and disappear, and are amended or maintained according to a plurality of legal relations. This affects the justification of the involvement of certain individuals in the proceedings; the links between the parties and with the institutions; the primacy of the parties' autonomy as the superior criterion for the conformation of almost every aspect of the arbitration -its existence, conduction and termination-; the relationships with third parties who are neither the parties nor the arbitrators and their entailment with them; the function of the arbitrators and the nature of the duties derived from the acceptance of their appointment; the design of the procedural rules; the incidence of procedural mandatory rules; the deadlines and their impact on the arbitral function; the findings of the tribunal and their essential components; the notification and communication regimes; the possible clarification, correction and complementation of the award; the effects of the award; the adoption of interim measures by the arbitrators; the enforcement of the award; etc.

And this leads necessarily to the -already- classic question: what is essential for arbitration: the autonomy of the parties and their freedom to submit to arbitration, or the arbitrators' function to solve the dispute according to the means -procedure- designed by the applicable legal order? Can arbitration exist without agreement? Can arbitration exist without procedure? 
Can an award and its res judicata effect exist without the arbitrators having performed the adjudicatory function through a procedure?

Every answer to all these questions reaches the same solution: it is not possible to have arbitration without any of the abovementioned pieces, which cannot but lead to the conclusion that "arbitration is arbitration", and this is its legal nature ${ }^{3}$.

Two fundamental elements constitute its essence. The freedom and autonomy of the parties, on the one side, and the exercise of the function of the arbitrators and its effects, on the other. There is not arbitration without them.

A) Freedom and party autonomy: Arbitration is based on the freedom and autonomy of the parties. Citizens are the holders of private rights, which they can transact; the creation, modification and termination of their relations is rooted in their freedom of contract; and the Constitution recognises those freedom and autonomy as essential elements of the legal order. It follows that there is not an obstacle against the parties' decision to have their disputes solved out of national courts, which together with the State have the monopoly of judicial power.

B) Adjudicatory function (heterocomposition): Arbitration is an adjudicatory mechanism for the resolution of legal disputes which, despite its ancient origin, has been decisively promoted in the last years within the framework of Alternative Dispute Resolution (ADRs). Three steps can be distinguished: self-tutelage, self-adjudication and external-adjudication.

a) Self-tutelage is the most primitive manner to resolve a dispute, consisting on "taking the law into your own hands", which transforms the interested party into his/her own judge (in re propia) and leads to partial and selfish intervention ${ }^{4}$. This form of tutelage is prohibited by the legal system, except in exceptional situations such as self-defence and overriding necessity.

b) Self-adjudication implies the solution of disputes from the recognition of the autonomy of the parties to transact upon their own private matters. From this perspective, the transactionality of the subject matter makes it possible for the parties to adjudicate or determine their dispute, either directly between them or with the assistance of a third party

\footnotetext{
${ }^{3}$ BARONA VILAR, S., "Introducción", in Comentarios a la Ley de Arbitraje. Ley 60/2003, de Arbitraje, de 23 de diciembre, tras la reforma de la Ley 11/2011, de 21 de mayo, Thomson Reuters-Civitas, Pamplona, 2011, pp.71-72.

4 ALCALÁ-ZAMORA y CASTILLO, N.: Proceso, autocomposición y autodefensa, UNAM, México, 1970, pp. 47 et seq.
} 
that does not impose a solution (and therefore cannot bind the parties). Different modalities of self-adjudication include popular institutions such as mediation ${ }^{5}$ and conciliation, which still plays a relevant role in certain jurisdictions.

c) External adjudication is the most developed formula of dispute resolution. It is characterised by the participation of a neutral person who solves the conflict between the parties through an instrument called "procedure" that is regulated by the law. The legal system recognises two forms of external adjudication: Judicial jurisdiction and Arbitration. Both feature a conceptual trilogy for their operation:

1) Organs which are subject to legal requirements and guarantees (essentially, the impartiality) and exercise the adjudicatory function through the imposition of a decision;

2) Parties who resort to those organs for the resolution of their dispute, intervene in confronted positions and must be protected by the principles of equality and contradiction, as generally provided by the law, and

3) A means, the procedure, through which the adjudicatory function is exercised.

On these bases, arbitration is the adjudicatory mechanism by which parties exercise their freedom to submit their dispute to arbitrators, who are subject to the applicable arbitral regime. The arbitrators, whose activity is directed by the autonomy of the parties and is subject to the limits imposed by mandatory rules or ius cogens, decide the conflict in an award after the conduction of the arbitral proceeding, which is the procedural instrument. Such decision is binding and enforceable, so that in case of non-compliance the parties can resort to the national courts to request the compulsory compliance with the solution contained in the award.

The origin of the institution can be found in Roman Law. In this vein, scholars argue that arbitration was the origin of the procedure ${ }^{6}$, that is, that the decision by an unofficial arbitrator

\footnotetext{
${ }^{5}$ Mediation has a promising future in the majority areas of the law, since it is based on the intervention of a third party alien to the dispute, who assumes the function to gather the parties and assist them in the resolution of their disagreement. That third party can be the judge, a lawyer, a psychologist, a therapist, a psychiatrist, etc. The success of mediation lies upon the interchange of information, bearing in mind that negotiations frequently start with reciprocal mistrust, and it is for the mediator to progressively build the trust between the parties to get them involved in the mediation technique, fragmenting the dispute, creating options and requesting them to suggest solutions, assuming, in sum, that the adopted agreement must be the result of the participation of the parties accepting their position and trying to solve their conflict. It is for this reason that the workability of mediation will depend substantially on the elimination of the reciprocal or unilateral hostility of the parties.

${ }^{6}$ WLASSAK, M.: “Der Gerichtsmagistrat im gesetzlichen Spruchverfahren”, in ZSS 25 (1904), p. 139 , note 1.
} 
was in fact the first form of justice ${ }^{7}$. With the pass of centuries and alongside the progressive strengthening of the political structure of the State, the arbitral formula lost relative importance ${ }^{8}$. The $18^{\text {th }}$ and $19^{\text {th }}$ centuries, the European codification period, were permeated by the bourgeois spirit and its idea of freedom, which also inspires arbitration. In that period the procedural influence of arbitration was evident. The $19^{\text {th }}$ century, however, should not only be highlighted for regulating arbitration in procedural Codes, but also for conferring a constitutional treatment to it. Although arbitration did not appear in subsequent Constitutions, this was not an obstacle for the peaceful coexistence of national judicial jurisdiction and arbitration, without posing any threat on the jurisdictional exclusivity recognised in all Constitutions.

The $20^{\text {th }}$ and $21^{\text {st }}$ centuries represent an important development in the regulation of arbitration. The first pieces of legislation in this field were Act on Private Arbitration, a purely contractual conception of arbitration and restricted it to resolution of private disputes, wrongly excluding economic conflicts. Some decades later, the Act sought to palliate the deficiencies of the rigid contractual approach of the preceding regime, and adopted a mixed conception: the basis and source of arbitration is an arbitration agreement, whose contractual nature is out of doubt, although the conduction of the proceedings and the arbitrators' function is inspired in the jurisdictional approach.

The presence of arbitration throughout the centuries has been persistent, although much development is still to come for this institution, which favours the peaceful resolution of disputes. It is doubtless, however, that it is currently a popular mechanism, and it will continue being so in the future. Because of this reason arbitration has integrated one of the piece of the new paradigm of Justice. The introduction of arbitration within the framework of legal relationships as a mechanism for the resolution of disputes has represented an exponential metamorphosis in last decade. This social, cultural, operative transformation is not only motivated by the adaptation of arbitration laws, but also by a political attitude, which has inserted into the legal system the necessary pieces to position the different country as centres for international arbitration.

Arbitration has, in sum, consolidated as one of the fundamental tools for the modernisation of Justice. Beyond its role as one of the excluding alternatives, its incorporation as one of the

\footnotetext{
${ }^{7}$ D'ORS PÉREZ-PEIX, A.: "La experiencia histórica del arbitraje jurídico", en Cuadernos informativos de derecho histórico, público, procesal y de la navegación 15-16 (1993) 3648.

8 With regard to the history of arbitration, see MERINO MERCHÁN, A., El arbitraje. Estudio histórico jurídico, University of Seville, 1981.
} 
pillars of the new paradigm Justice for the $21^{\text {st }}$ century is a manifest reality for the international, plural and entrepreneur citizen, for the private and public sectors, for the business community.

Undoubtedly International commerce and international commercial arbitration has been a great role. Arbitration has always been present among the codifying efforts, as evidenced by the early approval of the Geneva Protocol on arbitration clauses of 24 September 1923 and the Geneva Convention on the execution of foreign arbitral awards of 26 September 1927. The CNUDMI, which is in charge of the administration of the New York Convention, has performed a remarkable task in the arbitration field. This includes the publication of a series of international arbitration texts. The Model Law on international commercial arbitration of 21 June 1985 constitutes a prime example. Its soft law nature and complex elaboration represent a milestone in the legal regime of international commercial arbitration in the last decades and it has illuminated the adoption or modification of arbitration laws in more that 100 jurisdictions. Later, in 2006 two different changes altered rules about interim measures by arbitrators and some formal elements of agreement.

The new rules presented arbitration in a different manner as to how it had been perceived in the past. The incardination of arbitration in the society has progressively, albeit slowly, acquired relevance in the dispute resolution arena and a solid arbitral culture has appeared visibly among consumers and legal professionals. This is equally valid for domestic and international arbitration. And now could be said, that arbitration is a piece of the new paradigm of the 21 st century's Justice.

\section{Reasons of the new paradigm of Justice}

The 21 st century showed and shows us a new society, completely different to the one that had been built in the twentieth century.

The transition from the social state to the neoliberal and postmodern state, the economic globalization, the increase of real and social inequalities, living events in real time, the invasion of technology, the promotion of transnational, regional movements, the cult of Economic "efficiency" and an obsessive attention to security - but not to that of the individual but to that of society - among others, have gradually relegated those values that so many efforts and tears provoked in the past to create a society without borders, with a more fluid 
and simple legal traffic, with many doses of uniformity and with clear losses of individual, social and even state identity.

\section{1. "Glocalization" and influence in the legal sphere}

In this context, the so-called glocalization emerges in the legal sphere. Term used by sociologists Roland Robertson ${ }^{9}$ and Ulrich Beck ${ }^{10}$, that allows to speak of "to think globally and act locally". The "glocalization" is very present in the matter of Justice. We just have to observe the lines of action of the legislators and the tendencies towards a homogenization of Justice in numerous legal systems.

So, we can affirm that this glocalization of justice entails:

1.- Firstly, there is a great similarity, if not identity, in the responses that the various national legal systems offer in the area of justice. These replies are based on a global concept of legal certainty and guarantees.

2.- Secondly, some of the functions that in the twentieth century were of the exclusive competence of the State are now outsourced. The mediators appear and the arbitrators consolidate and have a function in this new paradigm of Justice.

3.- The old paradigm of liberal justice, established in the State as a power structure, as a political entity, and guarantor of the rights of its citizens, is giving way to a different scenario in which the same States are giving up part of their sovereignty. Now the process is not the only way and judges are not only actors in the world of Justice.

4.- Crisis and Metamorphosis. There is a real paradigm shift. A crisis of the model; A crisis that appears as a faithful reflection of a change in the essential values that direct the new perspectives of Justice in postmodernity; In which - undoubtedly - the efficiency of the model is prima facie compared to the satisfactory protection of citizens. A true metamorphosis takes place, with a disturbing and paradoxically contradictory scenario in certain cases.

5.- Change of the standards of Justice. Extrapolating this idea of a paradigm shift, is undoubtedly that in the modern, current, global, economic, digital, technological, and also liquid society in which we move, the parameters or standards of justice have changed. We live in an increasingly complex society.

\footnotetext{
${ }^{9}$ ROBERTSON, R., "Glocalization: Time-Space anmd Homogeneity-Heterogeneity", in FEATHERSTONE, M.,; LASH, S; ROBERTSON, R. (ed), Global Modernities, London: Sage, 1997, pp. 25-44.

${ }^{10}$ BECK, U., What Is Globalization?, Cambridge Polity Press, 1999.
} 
If the industrial revolution of the eighteenth and nineteenth centuries was developed leaving intact layers of society, the technological revolution of the 20 th and $21^{\text {st }}$ centuries, with its included crisis (ideological and economic), affects all layers and social spheres, altering their bases, generating new legal realities and, with them, new types of litigiousness.

6.- "Litigation explosion". A phenomen that OLSON named "litigation explosion" took place at the end of the $20^{\text {th }}$ century and specially during the 21 th century. Although this author referred to the situation in the United States of America, certainly the photograph of the litigiousness has been extended, becoming an element indissolubly linked to modern society.

The litigation explosion had a lethal effect on the model of justice to which our society was traditionally linked, and in which the State is the holder of the jurisdictional power, and its courts, those who judge and enforce what was tried. That was the paradigm of classical justice expanded worldwide for Centuries. This litigation explosion promotes an increase in the duration and cost of litigation, affecting citizens, in addition to increasing the workload of the courts and the inoperability of the State to offer the citizen a fast, efficient and more accessible model of conflict resolution.

7.- Frustration. The paradigmatic model of justice is subjected to pressure, is not able to fulfil the expectations generated by the parties as a system to ensure full compliance with the right to Access justice. This tense is reflected to one degree or another in many countries of the world, and in that unstoppable and feverish legislative activity that tries to adapt an "analogical" and static Justice to a "digital", flexible, with real time Access.

This metamorphosis of Justice in the glocalized society implies for some people an evolution, a transformation or a change; For others, an identity crisis.

\section{From Metamorphosis to the new Landscape of Justice. New Elements}

In this described context this new landscape of Justice have several and different incorporated components.

1.- One, Inspiring criteria for the change: efficacy and efficiency prevail over any other parameter. Becker and Posner, authors of the Economic Analysis of Law, are present in the new legislation. It is about cost and benefit. Seeking Justice at the lowest cost is one of the criteria underlying the unstoppable reforms that are taking place all over the world 
2.- Second, A worldwide proliferation of rules and regulations is occurring without control, generating a situation of ánomy, specially, in continental legal systems.

3.- Third, The roles in the judicial procedure have changed. The judge is now proactive, with increased managing and decision faculties. And the role of women in the legal area has grown exponentially. The number of female judges, female lawyers, etc is highly representative.

4.- Fourth, The procedural system is based on orality, openness to the public, agility, reduced cost and increased participation of the parties. Legal institutions that facilitate these elements have been incorporated to the process, allowing different acts to take place in less time.

5.- Fith, We are moving towards the so-called eJustice or electronic Justice, removing the use of paper, to develop, either the whole civil process or only some acts, through electronic means. Our Justice now includes videoconferences, digital signatures, electronic documents and electronic communications.

6.- Sixth, A new concept has emerged: consumers. There is an economic vision of who should be protected. The law is interested in protecting the consumer, who has replaced the concept of the citizen. In this way, consumer rights, consumer protection, consumer associations ... and means to protect consumers in a fast, agile, flexible, dynamic way, with special rules have appeared. The consumer's protection is a new face of Justice.

7.- Finally, ADR mechanisms are nowadays key elements in the model of Justice. Not only negotiation and mediation but too arbitration, and not necessary general arbitration but too sectorial different arbitration, as for instance maritime arbitration or consumer arbitration.

\section{ADR-ODR Mechanisms}

Among the different movements that appeared during the $20^{\text {th }}$ century, we can highlight the one linked to what legal theory called legal realism. This movement, which emerged in the United States, was a response against the government-stablished system for dispute resolution. Starting in Harvard University, it suffered an extraordinary development in the seventies. Alternative mechanisms were gradually becoming essential parts of the American model of Justice, as a response to the litigation explotion that took place at the end of the 20 
th century. Therefore, negotiation, mediation, conciliation and arbitration were stablished as alternatives to a traditional judicial system.

To the contrary, ADR mechanisms in Europe still played a residual role until the end of the $20^{\text {th }}$ century, limited to some sectors and with a small implementation. However, during the last twenty years ADR mechanisms have been promoted and presented as a remedy against the lack of satisfaction with ordinary Justice.

A new concept of Justice appears, the Access to Justice broadens its scope of application, is what we call "global Justice" or the so-called "Multi-rooms Justice System", a new system in which ADR mechanism and ordinary jurisdiction coexist, including both "out of Court" and "in Court" methods. A new movement. Probably this movement sought the way to reach the most appropriate method to solve the conflict or even achieve a settlement, taking into account the typology of the conflict.

ADR methods contribute to a new perspective of Justice of the 21th century, a plural and global perspective, in which judicial process coexist with extrajudicial mechanisms that in some cases permit the avoidance of judicial actions and, in others, simply reduce them. So we can talk about shared Justice, a sort of Multi-door-Justice System. So we have now a global model that seems to have more advantages than disadvantages.

So, the objectives are:

1.- To create different dispute resolution methods.

2.- To reduce the cost that results from the increasing number of disputes, a difficult problem to manage in the short or mid-term.

For these reasons, we are nowadays experiencing a sort of fascination with the extrajudicial dispute resolution methods and, specially, for mediation and for special arbitration.

But in this moment of fascination, we should point out some concerns:

1.- On the one hand, its positive to have different methods to allow citizens to solve their disputes, specially taking into account that some of these mechanisms involve a way to face human relationships, contribute to self-responsibility and favour communication, comprehension and listening between parties.

2.- On the other hand, however, the implementation of ADR mechanisms is not neutral. I mean, ADR mechanisms involve the participation of private professionals, outside the government structure, obviously this implies a lower cost for the ordinary Justice system and, 
therefore, for the state budget. Public expenses could be reduced. This consideration is present and can be attractive, but also quite dangerous if we are talking about Justice ${ }^{11}$. The governments could seek more efficiency at a lesser cost and this would result in a gap between rich and poor ${ }^{12}$.

Being aware of the great benefits that ADR mechanisms have, such as reducing conflicts, cutting the distance between parties and promoting the building of mutual respect; being also aware of the huge advantage that global Justice implies, a system in which courts, ADR methods, mediators, arbitrators, etc., coexist, allowing an improvement of the traditional system, increasing agility and promoting the termination of the conflict and, therefore, citizens satisfaction; it's sad to observe how, sometimes, the politicians observe Justice, courts and ADR methods as a sort of nuisance, forgetting that Justice is an essential pillar of a democratic state.

\section{CONCLUSION}

To finish, in sum we can talk about a new Justice paradigm. Promoting a model of global Justice that includes jurisdiction and ADR, new legal actors whose aim is, in essence, to improve the protection of citizens, is not only possible, but also highly recommended, provided that the trees (economically driven) allow us to see the wood. And Arbitration, simultaniously with this model of public justice, has been a part of Civil Justice in the history. Arbitration has been and is an adjudicatory mechanism for the resolution of legal disputes which, despite its ancine origin, has been decisively promoted in the last years within the frame work of Alternative Dispute Resolution (ADR), and more and more On line Dispute Resolution.

\footnotetext{
${ }^{11}$ WAGNER, G., "Harmonization of Civil Procedure-Policy Perspectives", en X.W.KRAMER and C.H. VAN RHEE, Civil Litigation in a Globalising World, Heidelberg, Springer, 2012, 93 and 112.

${ }^{12}$ ESPLUGUES MOTA/BARONA VILAR (ed), "ADR Mechanisms and their Incorporation into Global Justice in the Twenty-First Century: Some Concepts and Trends", en Global Perspectives on ADR, Cambridge, Ed Intersentia, 2014, pp- 1-52.
} 


\section{BIBLIOGRAPHY}

--ALCALÁ-ZAMORA y CASTILLO, N.: Proceso, autocomposición y autodefensa, UNAM, México, 1970

---BARONA VILAR, S., "Introducción”, in Comentarios a la Ley de Arbitraje. Ley 60/2003, de Arbitraje, de 23 de diciembre, tras la reforma de la Ley 11/2011, de 21 de mayo, Thomson Reuters-Civitas, Pamplona, 2011

---BARONA VILAR, S., "The Faces of Civil Justice in the Global Society of the 21st Century", ZZP Int. 21 (2016).

---BECK, U., What Is Globalization?, Cambridge Polity Press, 1999.

--- D’ORS PÉREZ-PEIX, A.: “La experiencia histórica del arbitraje jurídico”, en Cuadernos informativos de derecho histórico, público, procesal y de la navegación 15-16 (1993) 3648.

---ESPLUGUES MOTA, C.: “China's Accession to WTO”, in BU, Y.: Chinese Business Law, C.H.Beck/Hart/Nomos, Munich/Portland/Baden Baden, 2010.

---ESPLUGUES MOTA/BARONA VILAR (ed), “ADR Mechanisms and their Incorporation into Global Justice in the Twenty-First Century: Some Concepts and Trends", en Global Perspectives on ADR, Cambridge, Ed Intersentia, 2014.

--- MERINO MERCHÁN, A., El arbitraje. Estudio histórico jurídico, University of Seville, 1981.

---OLSON, W.K., The litigation explosion: what happened when America unleashed the lawsuit, 1991.

--- ROBERTSON, R., “Glocalization: Time-Space anmd Homogeneity-Heterogeneity”, in FEATHERSTONE, M.,; LASH, S; ROBERTSON, R. (ed), Global Modernities, London: Sage, 1997.

---WAGNER, G., "Harmonization of Civil Procedure-Policy Perspectives", en X.W.KRAMER and C.H. VAN RHEE, Civil Litigation in a Globalising World, Heidelberg, Springer, 2012.

---WLASSAK, M.: “Der Gerichtsmagistrat im gesetzlichen Spruchverfahren”, in ZSS 25 (1904) 